Hozzáférhetőség és technológia - Digitális akadálymentesítés az információs társadalomban: a Webtől a 3G telefónián át az intelligens otthonokig

(Patrizia Bertini: Accessibilitá e tecnologia Dal web alla telefonia 3G alla domotica: la sfida dell'accesso alla societa dell'informazione)

Így hivatkozzon erre a cikkre:

Simák Julianna, Borovitz Tamás. „Hozzáférhetőség és technológia - Digitális

A folyóiratban közölt müvek

a Creative Commons Nevezd meg! - Ne add el! - Így add tovább! 4.0

Nemzetközi Licenc feltételeinek megfelelően használhatók. 


\title{
Hozzáférhetőség és technológia
}

\section{Digitális akadálymentesítés az információs társadalomban:}

\section{a Webtől a 3G telefónián át az intelligens otthonokig}

\author{
Patrizia Bertini: Accessibilitá e tecnologia Dal web alla telefonia $3 \mathrm{~g}$ alla \\ domotica: la sfida dell'accesso alla societa dell'informazione
}

Miért van szükség arra, hogy valaki könyvet írjon a fogyatékkal élők hozzáféréséről az IKT eszközökhöz? A könyv ajánlásában Cristina Delogu és Daniela D’Aloisi azt a választ adják erre a kérdésre, hogy a 2003. év a fogyatékkal élők éve, és ez a legjobb alkalom arra, hogy a programozók és a webmesterek figyelme végre feléjük forduljon. Másik érvük a társadalmi változásokra utal: a számítógépek egyre inkább mindenki által elérhetôvé és felhasználhatóvá válnak, nemcsak kevesek munkaeszközei többé. A programozók egyre több szoftvert vetnek alá nyilvános tesztelésnek, és egyre nố a programok felhasználóinak száma. Még egy fontos megjegyzés a szoftverekről: az egyes alkalmazásokat nem elég csak lefordítani a felhasználó ország nyelvére, ezen kívül meg kell teremteni a felhasználás feltételeit is, köztük az eszközökhöz való hozzáférést, és biztosítani kell a megfelelố ismeretek elsajátítását.

A kötet bevezetőjében Salvatore Romano a vakok olaszországi szövetségének nevében üdvözli a könyv létrejöttét. Véleménye szerint a vakok és gyengénlátók életében a számítógépek használata minőségi ugrást jelen az „olvasás” tekintetében, mivel a számítógép képes az írott szöveget hanggá alakítani; valamint az írás területén is, hiszen a vakok ugyanúgy képesek a billentyúzetet kezelni, mint a látók - a gépíróknak sincs szükségük arra, hogy lássák a billentyúzetet. Triesztben már 1983-ban szerveztek egy bemutatót a vakírás és a számítógép összekapcsolásának lehetôségérôl, és a nyolcvanas évek végére már a vakok és gyengénlátók számára is megteremtôdtek az MS-DOS rendszer felhasználásának feltételei. Romano kiemeli, hogy Olaszországban a társadalombiztosítás rehabilitációs programok keretében támogatja a személyi számítógépek és a kiegészítố berendezések vásárlását.

Szintén a bevezetóben olvasható Alessandra Re véleménye is, aki a Torinói Egyetem docense és ugyancsak remek kezdeményezésnek minôsíti a könyv megírását. Fontosnak tartja, hogy a 2003. évet a fogyatékkal élőknek szentelték, ugyanis minden tizedik európai valamilyen fogyatékossággal él, s ez a munkaerôpiac szempontjából óriási veszteséget jelent. Re hangsúlyozza, hogy a sérültek mellett az idôseket is be kell kapcsolni az aktív munkába, hiszen az emberi életkor kitolódott, tehát a nyugdíjaskorúak egyre nagyobb számban vannak jelen az európai társadalmakban.

A szerzô mindenekelốtt azt a kérdést vizsgálja meg, hogy mit jelent a hozzáférhetôség. Véleménye szerint nemcsak azt, hogy felhasználhatjuk az új technológiákat, 
hanem azt is, hogy a technológián keresztül új információk, szolgáltatások válnak elérhetővé. Három területet tart kiemelkedôen fontosnak:

1. a szúkebb értelemben vett fogyatékosságot;

2. a tágabb értelemben vett fogyatékosságot, beleértve az időskorúak problémáit és nehézségeit a technika vívmányaival kapcsolatban; valamint

3. a technológiai újításokat és a vállalatok világát, ami jó üzletpolitikával gazdasági sikereket érhet el ezen a téren is.

A könyv egyrészt interjú-kötet, másrészt kutatási beszámoló, amely a legfrissebb adatokkal mutatja be az aktuális helyzetet, s emellett a hozzáférhető weboldalak készítésével kapcsolatos konkrét informatikai és programozási ismereteket is tartalmaz. Ez az elsố széles körû áttekintést nyújtó olasz nyelvú könyv a témáról.

A továbbiakban a könyv elsô részével kívánunk részletesen foglalkozni, elsôsorban a felhasználók világára, a nemzeti szintủ (kormányzati) programokra és a nemzetközi kezdeményezésekre koncentrálva. A könyv második és harmadik fejezetében ismertetett programokkal és azok múködésével, a műszaki paraméterekkel és a programozási tudnivalókkal nem foglalkozunk.

\section{Hozzáférhetőség és használhatóság}

A 2000. év új korszakot nyitott az olasz internetezés történetében. Ekkor jelent meg Olaszországban Jakob Nielsen könyve, mely a világhálót a felhasználók szemszögébôl elemzi, nem a technika oldaláról. A technikai fejlődés némileg kaotikus évei után végre a felhasználó került a középpontba, ő lett a főszereplő, a 'célszemély'. Bertini diagramok segítségével mutatja be, hogy ennek a szemléletváltásnak mekkora hatása volt, milyen ugrásszerúen nôtt a felhasználók száma.

Nielsen rámutatott a Web hibáira és a fejlesztés lehetséges irányaira. Véleménye szerint ha egy hétköznapi ember nem boldogul egy-egy weboldal használatával, ha nem jut el a keresett információhoz, akkor ez nem az ô hibája, hanem az oldalak készítôié.

Mit értünk a használhatóság fogalma alatt? A Nemzetközi Szabványügyi Szervezet (ISO) meghatározása szerint a használhatóság hasznos és hatékony tartalomelrendezést jelent, ami biztosítja, hogy a felhasználó eljut a megjelölt célhoz és helyhez. A téma neves olasz szakértôje, Michele Visciola szerint egy web-oldal használhatóságához az is hozzátartozik, hogy a felhasználó könnyen és egyszerúen tud az adott oldalon navigálni, s az megadja számára az összes keresett információt.

Nielsen éppen a kellő pillanatban „robbant be” az informatika világába. Ekkor már nagyon sok olyan weboldal létezett, amelyeket csak a készítőik tudtak használni. Ố mutatott rá arra, hogy ezeket elérhetôvé és könnyen kezelhetôvé kell tenni mindenki számára.

Mit értünk hozzáférhetöségen? Az 1973. évi olaszországi rehabilitációs törvény egyik módosítása szerint egy honlap akkor hozzáférhetô, ha a fogyatékkal élők is ugyanolyan könnyen tudják elérni és használni, mint a nem fogyatékosok. Egy másik megfogalmazás szerint a hozzáférhetőség egyet jelent annak megtervezésével, ho- 
gyan tudja minél több ember minél több szituációban hatékonyan használni az adott oldalakat, függetlenül a felhasználók iskolai végzettségétôl, az elérés módjától, a felhasználás helyétôl és az ehhez igénybe vett technikai apparátus színvonalától.

Az elektronikus információ hozzáférhetôségének normáit, amelyek azóta is standard mércét jelentenek az informatika világában, először 1992-ben határozta meg az akkor a hozzáférhetô dokumentumok tervezése érdekében megalakult nemzetközi bizottság, az International Committee for Accessible Document Design (ICADD). 1997 ismét fontos esztendő volt, mivel a világháló működésének szabványait kidolgozó World Wide Web Consortium (W3C) ekkor indította útjára a „Hozzáférhetô világháló kezdeményezése" (Web Accessible Initiative) elnevezésû programját, melynek keretében nyilvánosságra hozta a böngésző, multimédia lejátszó és egyéb hálózati szoftverek kifejlesztése során alkalmazandó irányelveket.

Az informatikusoknak nem csak a csúcstechnológia fejlődését kell folyamatosan figyelemmel kísérniük, hanem azt is, miként lehet elérni, hogy a világháló valóban mindenki számára elérhető legyen. Bertini többször is nyomatékosítja, hogy nemcsak a szúkebb értelemben vett fogyatékkal élốkre kell gondolni, hanem például a gyengénlátókra, a diszlexiásokra és az idősebbekre is, akik esetleg Parkinson kórban szenvednek vagy csak az emlékezóképességük lett gyengébb. Nem zárhatók ki továbbá ebból a körból azok sem, akik ideiglenes fogyatékosságban szenvednek, például mútéti beavatkozáson estek át, s a cselekvőképességük ezért korlátozott. Azok is ide tartoznak, akik olyan környezetben élnek, ahol nem állnak rendelkezésre a legkorszerûbb technikai feltételek. A hozzáférés tekintetében előfordulhatnak idôszakos nehézségek is, például a túlságosan zajos környezet, a helyi világítás hiánya, vagy éppen a túlzottan megvilágított környezet. A szakembereknek mindezeket figyelembe véve kell az eszközöket megtervezni.

A mindennapi élet tevékenységei közül a szerzô a vásárlást és a bankügyleteket emeli ki, több példát hozva arra, hogy a fogyatékkal élóket mennyiben és miként segítik a számítógépek az ügyintézésben. Kiemeli, hogy ezek nem helyi problémák, amelyeket tetszés szerint vagy a helybeli szolgáltatások adott színvonalától függốen lehet kezelni, ugyanis a fogyatékosok jogait és lehetőségeit ezen a téren nemzetközi egyezmények és szerződések rögzítik.

\section{A fogyatékosság meghatározása}

A fogyatékosság komplex fogalom, amit nehéz pontosan meghatározni. A definíció megalkotásakor mindenképpen ki kell emelni a képességek vagy a lehetőségek hiányát, illetve korlátozott voltát. Különbséget kell tenni továbbá a csökkent képesség és a képesség teljes hiánya között. Mindkettônek szükségszerú következménye az egyén hátrányos helyzete. A könyv tételesen számba veszi a különféle fogyatékosságokat.

A fogyatékkal élőknek az összlakossághoz viszonyított részarányára vonatkozó statisztikákat vizsgálva meglepően nagy számokat találunk, ráadásul ez az arány a statisztikai kimutatások tükrében sajnos növekvő tendenciát mutat. Az 1980. évi olaszországi felmérések szerint az olasz népesség 5 százaléka küszködik valamilyen fogyatékossággal. Európában mintegy 37 millió a sérültek száma. A világ népességének kö- 
zel 10 százaléka sérült, s közülük 61 százalék halmozottan fogyatékos. A munkaképes korban levố fogyatékosoknak csak 17,4 százaléka áll alkalmazásban. A szerző diagramok segítségével mutatja be a fogyatékosok életkor és nemek szerinti megoszlását, valamint azt is, hogy közülük hányan élnek családban, illetve egyedül. Olaszországban a különféle fogyatékosságok között elsố helyen a hallásproblémák állnak (600.000 siketet és hallássérültet, 350.000 vakot és 300.000 értelmi fogyatékost tartanak nyilván).

A fogyatékosságokat Bertini a következőképpen csoportosítja:

1. szenzorikus fogyatékosságok,

2. motorikus fogyatékosságok,

3. kognitív fogyatékosságok.

Az első csoportba mindazok a fogyatékosságok tartoznak, amelyek az öt érzékszervvel vannak kapcsolatban. Az Internet használatát a vakok számára a legnehezebb lehetôvé tenni. A legegyszerúbb Braille billentyúzet mindössze 20 karakterbôl áll, de készítenek bonyolult, 40, 70 vagy 80 karakteres billentyűzeteket is. Ezeknek az a hátrányuk, hogy egyeloóre még nagyon drágák és megvásárlásukat a társadalombiztosítás nem mindenütt támogatja. Az olvasást többféle képernyő-felolvasó készülék segíti, és léteznek olyan böngésző programok is, amelyek hallhatóvá teszik a képernyő tartalmát. A siketek problémái például kiegészítő feliratok, fényjelek segítségével könynyebben kezelhetôk.

A második csoportba a mozgásszervi megbetegedések tartoznak. Ezek a fogyatékosságok lehetnek veleszületettek, és okozhatja ôket betegség vagy baleset is. Ide tartozik a teljes vagy részleges rokkantság, valamely testrész hiánya, a végtagok bénulása vagy mozgatásuk kontrolljának elvesztése. A mozgássérültek számára speciális például megnagyobbított vagy lábbal is kezelhetô - billentyűzetek, valamint szájjal mozgatható kiegészítô berendezések, pedállal múködô egerek és fejhez illeszthetố eszközök készülnek.

A fogyatékkal élők harmadik csoportjába a diszlexiások, diszkalkuliások, epilepsziások és különféle egyéb idegrendszeri betegségekben szenvedők tartoznak. Az ô esetükben nincs szükség speciális hardverekre, de számukra olyan szoftvereket kell kifejleszteni, amelyek hozzásegítik őket az információk megszerzéséhez: ezek lehetnek különféle tanulási (olvasásfejlesztési, szövegértési) programok vagy olyan alkalmazások, melyek segítségével a felhasználók egyszerre hallhatják és olvashatják is a szöveget.

\section{Az elérhetőség törvényi szabályozása}

A szerző ebben a fejezetben azt a kérdést teszi fel, hogy a hozzáférést jognak vagy kötelezettségnek kell-e tekintenünk, s leszögezi, hogy az információhoz való hozzáférés joga mindenkit megillet. A fejezet áttekintést nyújt a fogyatékkal élőkre vonatkozóan egyes országokban bevezetett jogszabályokról.

Elsốként az Egyesült Államokban, 1973-ban foglalták törvénybe, hogy a fogya- 
tékosok semmiben sem szenvedhetnek hátrányt más embertársaikkal szemben (Rehabilitation Act). Ennek oka abban is keresendő, hogy nemcsak a második világháborúból, hanem a vietnami háborúból is nagyszámú hadirokkant érkezett haza, akiknek a beilleszkedését meg kellett könnyíteni, és munkalehetőséget kellett biztosítani számukra. A törvény megtiltotta a diszkriminációt, és az ipart arra ösztönözte, hogy különféle eszközök gyártásával segítse elő a rehabilitációt. Ezek az intézkedések nemcsak a munkára, hanem az élet minden területére kiterjedtek, a szabadidős tevékenységektôl a sportolási lehetôségekig, a közlekedéstốl a szórakozásig.

Az 1981. évet az ENSZ a fogyatékosok évének nyilvánította, s ennek nyomán a nyolcvanas évek hatalmas szemléletbeli változásokat hoztak.

Kanadában 1985 óta van érvényben az emberi jogok törvénye (Human Rights Act), amely megtilt minden faji, nemek szerinti és vallási megkülönböztetést, s biztosítja a fogyatékkal élők jogait is, ideértve az utóbbiak részvételét a közlekedésben és a távközlésben, továbbá a fogyatékosok érdekeit szem elôtt tartva szabályozza a kiskereskedelmi, utazási és banki szolgáltatásokat. 1995-ben jelent meg a munkavállalás egyenlő esélyeit szavatoló törvény, 2000-ben pedig kiterjesztették a szabályozást arra is, hogy a web-oldalak elérhetőségét mindenki számára biztosítani kell.

Az emberi jogok biztosítása terén élenjárónak számító Ausztráliában 1992-ben vezették be a fogyatékossági törvényt (Disability Act): míg az Egyesült Államokban a törvény először csak a kormányzati honlapok teljes körú elérhetőségének biztosítását írta elô, az ausztrál törvény kötelezôvé tette ezt a kereskedelmi honlapokra vonatkozóan is.

$\mathrm{Az}$ afrikai kontinenst illetốen a kötet a legfejlettebb iparral rendelkezô, ám a földrészt természetesen nem reprezentáló Dél-Afrikai Köztársaságra tér ki részletesebben. Ebben az országban hosszú ideig azt tekintették az elsô számú feladatnak, hogy a személyi számítógépek számát megnöveljék, és ellássák számítógépekkel a középrétegeket is. 1998-ban hatályba lépett a munkához való egyenlő jog törvénye, amely előírja azt is, hogy a fogyatékkal élôk munkavállalásához biztosítani kell a megfelelő technikai eszközöket. A személyi számítógépek száma 2002. óta ugrásszerúen növekszik.

Az Európai Unió 2000-2002 között elért eredményeit a könyv az alábbiakban foglalja össze:

1. Az Internet otthoni felhasználása megduplázódott.

2. A hozzáférés költsége felére csökkent.

3. Az iskolák és a vállalatok túlnyomó többsége rendelkezik a hálózat elérését biztosító eszközökkel.

4. Európában jött létre a leggyorsabb kutatói hálózat.

5. Az e-kereskedelem törvényileg szabályozott.

6. Számos közigazgatási szolgáltatás elérhetố a hálózaton. 
Az elérendő célokat az eEurope 2002 elnevezésű stratégiai program jelölte ki, melyet 2000-ben fogadott el az Európai Unió. A kötet szerzője a következô célkitûzéseket emeli ki:

1. a fiatalok szerepének fokozása az információs társadalom kiépítésében,

2. az Internet használatának még olcsóbbá tétele,

3. az elektronikus kereskedelem felgyorsítása,

4. nagyobb sebességú adatforgalom biztosítása az Interneten,

5. személyes információkat tartalmazó intelligens kártyák kibocsátása,

6. a technológiába fektetett tőke kockázatainak csökkentése,

7. a fogyatékkal élők bevonása a felhasználók körébe,

8. a hálózaton elérhető egészségügyi szolgáltatások biztosítása,

9. intelligens szállítás

10. az online közigazgatási szolgáltatások fejlesztése.

A kötetben számos interjú található Belgium, Norvégia, Franciaország, Hollandia, Németország, az Egyesült Királyság, Írország és Olaszország illetékes szakértőivel, akik részletesen beszámolnak az országaikban érvényben levő törvényi szabályozásokról, a fogyatékkal élốk számára biztosított jogokról, továbbá azokról a technikai lehetôségekrôl és pénzügyi megoldásokról (például a társadalombiztosítás finanszírozási módjairól), amelyek megkönnyítik a fogyatékosok számára a beilleszkedést és az esélyegyenlőség elérését.

\section{Esettanulmányok, tapasztalatok és gondolatok az elérhetőségről}

A szerző két nagy port felvert esetet ismertet, amelyek a hozzáférhetőség törvényi szabályozása terén precedenst jelentettek. Az egyik az Egyesült Államokban történt, amikor az amerikai vakok képviseletében pert indítottak az egyik legnagyobb hálózati szolgáltató, az America Online (AOL) ellen, mivel az szolgáltatásait nem tette elérhetôvé a vakok számára, s az általa alkalmazott technológia nem volt kompatibilis a vakok számára készített eszközökkel. A perben hozott bírói ítélet kötelezte az $A O L$-t a technológia módosítására; ez az eset a nyomtatott és az elektronikus médiában is sokáig napirenden szerepelt.

A másik ügy a 2000-ben Sydneyben rendezett olimpiai játékok 'webkikötőjéhez' kapcsolódik. Itt nem egy szervezet képviselôje, hanem egy magánszemély perelte be az ausztrál olimpiai bizottságot, mert az a vakok számára nem tette lehetôvé az olimpiai oldalakhoz való hozzáférést. A keresetet benyújtó állampolgár rendelkezett Braille billentyưzettel, ám az általa beküldött írást az adott web-oldal gondozói nem tudták elolvasni, s így jegyet sem rendelhetett magának. A bíróság természetesen azonnal kötelezte az olimpiai bizottságot a szolgáltatás átalakítására.

A World Wide Web Consortium (W3C) nyitott egy honlapot, ahol megismerhetôk a hozzáférés elősegítése terén eddig elért eredmények és a további célkitűzések is. Ez a szervezet kutatásokat is végez, s számos fejlesztési programmal és különféle oktatóprogramokkal segíti az Internetre felvitt tartalmak elérhetôségének javítását. 
A könyv második részében a szerző a hozzáférés technikai oldalával foglalkozik. Ismerteti a világhálón megjelenô tartalmak hozzáférhetôségére vonatkozó irányelvek (Web Content Accessibility Guidelines, WCAG 1.0) gyakorlati alkalmazhatóságát, és kitér több programozási és weboldal-építési kérdésre is. A könyv harmadik része már a jövố technológiáját tárgyalja. A szerzô leír néhány szabványt és HTML-kiegészítést $(A$ DHTML, CSS, XML stb.), bemutatja ezek alkalmazásának lehetőségeit a fogyatékosok által is elérhető oldalakon, majd kitér a legmodernebb technológiákra, a mobiltelefonok harmadik generációjára és az intelligens otthonokra is.

A függelék néhány olyan szoftvert ismertet, amelyek a fogyatékosok számára megkönnyítik a böngészést a világhálón, majd átfogó képet nyújt a fogyatékosok jogait Olaszországban, az USA-ban, Kanadában, Ausztráliában, Japánban és az Európai Unió országaiban szabályozó törvényekrôl és törvénytervezetekről. A függelék harmadik része a web-oldalak hozzáférhetôvé tételével kapcsolatos költségeket mutatja be egyrészt a szolgáltatók, másrészt a felhasználók szemszögéből.

$$
\text { Simák Julianna - Borovitz Tamás }
$$

Patrizia Bertini: Accessibilitá e tecnologia; Dal web alla telefonia $3 g$ alla domotica: la sfida dell'accesso alla societa dell'informazione; PEARSON Education Italia, 2003 